\title{
Legal Construction of Nursing Accountability in Circumcision Practice
}

\author{
Panggih Sediyo'), Isharyanto'), Arief Suryono²) \\ 1)Masters Program in Law, Universitas Sebelas Maret \\ ${ }^{2)}$ Faculty of Law, Universitas Sebelas Maret
}

\begin{abstract}
Background: Circumcision is one of the surgical practices often performed by nurses in rural and urban areas. Minister of Health Decree No. 1239 of 2001 on the registration and practice of nurses has not provided clarity on the limits of authority and legal protection for certain nurses. Many nurses provide services in the community that are not in accordance with the rules and authority.

Subjects and Method: This was a normative study with statute, case study, and conceptual approach. Legal materials were collected using document review. Legal materials were analyzed by describing the problem under study.

Results: Article 65 of Law Number 36 the Year 2014 on Health Personnel provides delegation of authority from the doctor to the nurse if the doctor cannot perform a medical service, provided that the physician is obliged to provide clear written authority delegation to perform the medical service. Regulation of the Minister of Health of the Republic of Indonesia No. 17 of 2013 on Amendment to Regulation of the Minister of Health No. Hk.02.02/Menkes/148/I/2010 Concerning Permits and Implementation of Nurse Practices states that medical service can only be delivered based on written request from the doctor. Regulation of the Minister of Health of the Republic of Indonesia Number 17 the Year 2013 Concerning Amendment to Regulation of the Minister of Health No. Hk.02.02/Menkes/148/I/2010 Concerning Permission and Implementation of Nurse Practice Article 3a authorize Nurses to undertake nursing practice in health-care facilities outside of the solo practice.

Conclusion: Legal construction for nurses who practice circumcision provides legal certainty in the rules relating to solo practice so that there is a law protection. Ministerial Regulation does not have binding power. The researcher suggests that a more binding legal regulation of circumcision by nurses be developed, for example by adding to the provisions of Law No. 36 of 2014 .
\end{abstract}

Keywords: circumcision, health service, nursing accountability, legal protection, nurse authority

\section{Correspondence:}

Panggih Sediyo. Masters Program in Law, Universitas Sebelas Maret, Jl. Ir. Sutami No. 36 A, 57126, Surakarta, Central Java. Email: panggihsediyo@gmail.com. Mobile: +6285726509884.

\section{BACKGROUND}

Nurses as one of the actors in the implementation of health services have the competence in conducting professional nursing care to patients, not taking medical action. Nurses play a role in UKP (Individual Health Efforts) and Community Health Efforts (UKM). Nurses have multiple roles in all health service settings in each level of referral in which the form of services provided is a comprehensive biopsychosocial spi- ritual service. One of the authority of nurses that has been regulated in the regulation is to be able to practice nursing independently (Ismani, 2001).

Circumcision is one of the medical surgical practices that is often carried out by nursing staff (mantri) in rural areas even in urban areas. There are no regulations that explain the authority of nurses in carrying out circumcision surgery so that this practice is increasingly widespread by 
nurses in the countryside. The case that was rife occurred when a nurse carried out the circumcision act as follows: Ogan Komering Ulu District Police, South Sumatra, determined the circumcision assistant had the initials DL as a suspect for allegedly committing malpractice while circumcising DWP, an elementary school student in Baturaja, whose genitals are cut. The police chief of Ogan Komering Ulu (OKU), AKBP Leo Andi Gunawan accompanied by the Head of Reskrim, AKP Harmianto in Baturaja, said on Sunday that DL was immediately arrested in the Ogan Komering Ulu Police Headquarters cell. Determination of the suspect was an increase in the status of the circumcision mantri who had previously been reported. The legal fact in question is that investigators find the person concerned in carrying out health actions. As a result of his negligence, the DWP victims who were circumcised by the suspect suffered severe injuries in the form of a broken end of the victim's genitals. Whereas in practice, DL is not equipped with a permit or other registration letter which of course does not have the authority to carry out medical actions including circumcision, said police chief. The suspect DL is a nurse in one of the sub-health centers in BP Peliung sub-district, East OKU regency. When carrying out his illegal activities, the suspect was invited and picked up by the victim's father with the initials Shd on Thursday (10/11/2016) to circumcise. When the circumcision takes place, the victim's genitals are cut off and must be rushed to the hospital. The victim's family then chose to take the legal route by reporting the DL to the OKU Police Station which has now been handled by the police. "The suspect did not know why it could be cut off (the tip of the victim's genitals). We still covered it again so that it became clear," he said. He added, in order to strengthen the investigation and investigation of suspects so that they can be delegated to the public prosecutor, the police also confiscated and secured evidence from the suspect, such as a set of medical equipment commonly used for circumcision, namely scissors, gauze, syringes and others. Minister of Health Decree Number 1239 of 2001 concerning registration and practice of nurses, although confirming it as a profession, Indonesia apparently still does not provide clarity on the limits of authority, definite legal protection for nurses ("Wrong Cut, Mantri Circumcision Becomes the Suspect - News", no date).

In regards to the explanations above, it is necessary to conduct research about "Construction of Nurse's Law of Responsibility in Acts (Circumcision)". The problem that were examined are presented as follows: 1) How is the accountability of the nurse who carries out circumcision in terms of the relevant legislation?, 2) How is the construction of an ideal regulation for nurses to risk circumcision?

\section{SUBJECTS AND METHOD}

This was a normative legal study, focused on studying the application of norms or norms in terms of theoretical, principle, conception, legal doctrine and the contents of positive legal rules. Such research can be carried out primarily against primary and secondary legal materials, as long as the materials contain legal norms (Mamudji and Soekanto, 2006). The approach used by researchers in the writing of this law was the statute approach which is meant by the law are the laws and regulations, the case approach, and the conceptual approach.

The first one was the statute approach. This approach was used because the answers to the legal research problem will refer to the relevant legislation. In this case, the researcher will carry out the activities of 
description, systematization, and interpretation of the law. The positive law used in this approach includes the following laws and regulations:

a) 1945 Constitution of the Republic of Indonesia

b) Law Number 29 of 2004 concerning Medical Practices;

c) Law Number 36 of 2009 concerning Health;

d) Law Number 36 of 2014 concerning Health Personnel;

e) Law Number 38 of 2014 concerning Nursing

f) The Regulation of Ministry of Health NumberHk.02.02/MENKES/148/I/2010concerningPermits and Implementation of Nurse Practices

g) Regulation of the Minister of Health of the Republic of Indonesia Number 17 of 2013 concerning Amendments to the Regulation of the Minister of Health NumberHk.02.02/MENKES/148/I/ 2010 concerning Permits and Implementationof Nurse Practices.

The second one was a conceptual approach. The conceptual approach was depart from the views and doctrines that develop in the science of law. In this study, the authors was conducted a legal analysis related to the Construction of Nurse's Accountability Law in Circumcision. The next process were describe and explain these concepts in order to guide them in an efficient and effective manner.

The third one was the case approach. This approach was needed in order to see the relevant euthanasia case problems.

The technique of collecting legal materials was the study of documents or library materials. The technique of analyzing legal materials was by solving and describing the problems under the study based on the materials collected.

\section{RESULTS}

1. The accountability of nurses who perform circumcision in terms of relevant laws and regulations

a. Nurses are responsible for circumcision actions in health services

Circumcision is a minor surgery procedure with local anesthesia, including neonatal. There are two commonly used models of local anesthesia. The first one is by injecttion at either the base of the penis (DPNB) or the preputium (ring-block). The second one was using topical anesthesia, usually in the form of spray. The injection method is more effective, but in practice it depends on the circumcision technique used and the doctor's skills. The average time required is only about 10-15 minutes, as long as it is not difficult (Ferris et al., 2010).

Nurses also have responsibility for their duties, including:

a. The nurse's responsibility for the task.

1) Nurses always maintain high quality nursing services along with professional honesty in applying nursing knowledge and skills according to individual family and community needs.

2) The nurse must keep everything that is known in connection with the assignment entrusted to them except if required by the authorized person in accordance with the applicable law.

3) Nurses will not use nursing knowledge and skills for purposes that are contrary to humanitarian norms.

4) Nurses in fulfilling their duties and obligations always strive with full awareness in order not to be influenced by consideration of nationality, ethnicity, color, age, gender, political flow and adopted religion and social position.

5) Nurses always prioritize the protection and safety of clients in carrying out nursing duties and mature in consider- 
ing the ability to receive or transfer assignments that have to do with nursing. Based on Article 59 of Law Number 36 Year 2009 which regulates traditional health services consists of:

1) Based on the method of treatment, traditional health services are divided intotraditional health services that use skills and herbs

2) Traditional health services as referred to in number (1) are fostered and supervised by the government so that benefits and security can be accounted for and not contradictory to religious norms.

3) Further provisions concerning the procedures and types of traditional health services as referred to in number

(1) are regulated by government regulations.

Based on Article 60 of Law No. 36 of 2009 concerning Health, regulating traditional health services consists of:

a. Everyone who performs traditional services using tools and technology must obtain permission from an authorized health institution

b. The use of tools and technology as referred to in number (1) must be accounted for their benefits and security and not contradictory to religious norms and community culture

Circumcision is not included in traditional health services because nurses only use self-taught skills to perform circumcision actions. Nurses are not nurtured and not supervised by the government. Central Java PPNI Chairman, Edy Wuryanto while attending a circumsion national seminar some time agoexplained that his party was regulating the authority for nurses to open circumcision practices in accordance with applicable regulations. "In Central Java in particular, all nurses who want to open circumcision practice must go through the certification process. This is to improve the quality of nurses' competencies and ensure patient safety. Nurses who want to have circumcision certification, previously had to attend circumcision training and education. With the certification of circumcision, the community will increasingly trust the competence of nurses in performing circumcision practices. Because the certification is to maintain patient safety. Everyone who performs traditional services using tools and technology must obtain permission from an authorized health institution.

\section{b. Nurse medical responsibility}

Absolute responsibility is an artificial causing the consequences that are considered detrimental by the legislator and there is a relationship between action and its consequences. Accountability for law in the practice of circumcision is divided into 3 , such as (Hukun and Jambi, 2009);

1. Accountability by Civil Law

Civil law referred to in a medical action liability is an element of compensation if in a medical action there is a negligence or mistake made by medical personnel.

Civil lawsuits against nurses are based on two forms, namely violating the law (onrechtmatigedaad) in accordance with the provisions of Article 1365 of the Civil Code and contractual liability in accordance with the provisions of Article 1239 of the Civil Code.

According to Article 29 of the Republic of Indonesia Law Number 36 of 2009 which states that "In the event that health personnel are suspected of negligence in carrying out their profession, the negligence must be resolved first through mediation."

According to the provisions of Article 1336 of the Civil Code (KUH Perdata), everyone is responsible not only for losses caused by his actions but also for losses caused by negligence or lack of care, in assuming that the negligence is an act com- 
mitted by health personnel who serve in hospitals in providing health services to patients is certainly his responsibility, if there is a medical omission that because of things that do or do not do something that neglects the patient with certain reasons for example because there are no fees, or guarantor, resulting in the occurrence of disability and death for the patient, then the health personnel can be sued civil in case of negligence of the duties and responsibilities that should be done.

As in the case above, the nurse is negligent because of circumcision so that the patient suffered severe injury in the form of the end of the victim's genitals. It should be resolved through mediation first to demand compensation for the patient because he has been negligent in practice.

2. Criminal Law Accountability

Criminal law accountability of a new nurse can be held accountable if there are elements as follows.

a. An act that is unlawful in this case if the nurse carries out health services beyond the authority set forth in Article 8 of the Regulation of the Minister of Health Number 148 of 2010

b. Being able to be responsible, in this case a nurse who understands the consequences and risks of each action and ability, has received training and education for it. This means a nurse realizes that her actions can harm the patient, third; misunderstanding (schuld) in the form of intentions (dolus) or due to negligence (culpa), third; there are no justification reasons or forgiving reasons; in this case there is no reason to forgive such as the absence of rules that allow him to take an action, or there is no justification. In a health personnel practice, criminal liability arises if there is an evidence of an action in a health service that has an element of crime in accordance with the Book Constitution. Criminal Law and other laws (Subarkah, 2010). Criminal action in the practice of circumcision carried out by nurses as regulated in Article 191 of Law Number 36 of 2009 concerning Health, which stated that anyone who conduct traditional health services that used tools and technology without permission as referred to in Article 60 paragraph (1), resulting in loss of property, serious injury or mortality shall be punishable by imprisonment for a maximum of 1 (one) year and get a fine for maximum of Rp 100,000,000 (one hundred million rupiah). The above case explained that the nurse did not have a practice license and caused serious injury so that the nurse's actions could be subject to criminal accountability.

c. Administrative Law Accountability

Aministrative law accountability was born due to a violation of administrative law provisions regarding the implementation of nurse practice based on the applicable provisions. Minister of Health Regulation Number 148 of 2010 has provided administrative provisions that must be obeyed by the nurses, namely:

1. Nurse Practice License for nurses who practice independently.

2. The implementation of health services based on the authority in Article 8 and Article 9 with the exception of Article 10.

3. The obligation to work according to professional standards.

The absence of the administrative requirements above would make the nurses to be vulnerable to claims. The absence of CTS in running the health services was an administrative malpractice that can be subject to legal sanctions.

The basis of this administrative law was the Republic of Indonesia Law No. 36 of 2009 concerning Health, namely Article 
23 number (3), which stated that in providing health services, health personnels must have permission from the government. Article 24 number (1) stated that the health personnel as referred in Article 23 must fulfill the provisions of the code of ethics, professional standards, the rights of health services users, service standards, and standard operating procedures.

2. Ideal construction of the nurses' actions who perform circumcision

a. The provision of independent practice protection for nurse who perform circumcision

Nursing as an integral part of health services in Indonesia realized that the need for nursing services was universal for clients (individual, family, groups, and communities), therefore, services provided by the nurses were always based on noble ideals, pure intentions for the safety and welfare of the people without distinguishing the nationality, ethnicity, skin color, age, gender, political flow, religion, and social position. Therefore, structuring the nursing practice was based on humanity, scientific value, ethics, benefits, justice, protection, health, and clients safety('Nursing Legal Aspects as One of the Efforts to Deal with the Globalization Era of Rr. Tutik S Hariyati Lecturer in Basic Nursing FIK-UI', 1992). Legal protection was for nurses who conduct circumcision in independent practices. In the legal regulations regarding the nurses as a profession, it turned out that these regulations have the principle of legal protection for the nurses in carrying out their service duties. However, when nurses performed nursing care services in independent clinics, they did not get legal protection. This was due to ambiguity of multiple interpretations in working terms and practices in the work permit (WP) of nurses. This multi-interpretations lead to legal uncertainty so that nurses were not protec- ted by law in performing their service duties in independent practice facilities.

a) Legal Protection for the Implementation of Nursing Care Services in Independent Practices. The regulations governing the implementation of circumcision services have fulfilled the principles of justice, usefulness and legal certainty so that it can be concluded that the implementation of nursing care services for circumcision carried out by the nurses as profession workers have received legal protection. In the reality, the implementation of nursing care services for circumcision practice created confusion due to the mixing of functional positions and structural positions. Nursing care services were functional, however, the regulations governed them in structural positions that look at the position of health personnels and medical personnel in the hierarchy of an organization. This confusion lead to legal uncertainty in its orientation and implementation so that the implementation of nursing care services in independent clinics became legally unprotected.

b) Legal Protection for Independent Practice Licensing. The ambiguity that occurred between nurses' "Work" and "Practice" raised the multi-interpretation of the existing legal regulations. Besides the fact that the circumcision practices were included in the authority of the doctor, nurses can also perform the circumcision if there was a cooperation between doctors and nurses in the independent practice.

b. Ideal legal construction for nurses in independent practice of circumcision

Legal provisions which regulated the nurses who perform circumcision practices in the laws and the regulations implementation. Based on the hierarchy, the 1945 Consti- 
tution was the highest source of law and as a basic guideline in creating the other legislations.

Law Number 36 of 2014 concerning health personnels which confirmed that health personnels must have the qualifications according to Article 8, which stated that the personnels in the health sector were consisted of health personnel and health personnel assistant.

Law No. 36 of 2014, Article 9 stated:

1) Health personnels as referred to in Article 8a must have a minimum qualification of Associate Degree (D3), except for medical personnel.

2) Further provisions regarding the minimum qualifications of Health Personnel as referred in paragraph (1) shall be regulated by a Ministerial Regulation.

In this case, the qualifications of a nurse were regulated in the Regulation of the Minister of Health RI Number 17 of 2013 concerning Amendments to the Regulation of the Minister of Health Number Hk.02.02/MENKES/148/I/2010 concerning Permits and Implementation of Nurse Practices. Health Law Number 36 of 2009 Article 23:

1) Health personnels were authorized to provide health services.

2) The authority to organize health services as referred to in number (1) was done in accordance with the areas of expertise.

3) In providing health services, health personnels must have permission from the government.

4) In providing health services as referred to in paragraph (1), it was prohibited to prioritize the interests of financial values.

According to Article 65 of Law Number 36 of 2014 concerning Health Personnel, there was a devolution of actions if the action was in the form of the doctor authority and delegated to the nurse.
1) In performing health services, Health Personnel can receive medical procedures from medical personnel:

2) In conducting pharmaceutical work, technical personnel can receive pharmaceutical work delegation from pharmacists.

3) The delegation of actions as referred to in paragraph (1) and paragraph (2) was done with the provisions:

a. Delegated actions include the abilities and skills possessed by beneficiary recipients;

b. The implementation of the devolved action was under the supervision of the assignor;

c. The assignor was still responsible for actions devolved during the implementation of the action in accordance with the given delegation; and

d. Actions that were delegated did not include decision making as the basis for actions implementation.

e. Further provisions regarding the devolution of actions as referred to in number (1), number (2) and number (3) shall be regulated by a Ministerial Regulation.

According to Law Number 36 of 2014 Article 84:

1) Every health personnel who did severe negligence which caused the Health Service Recipient to be seriously injured shall be punished with a maximum imprisonment of 3 (three) years.

2) If severe negligence as referred to in paragraph (1) resulted in death, every health personnel shall be subject to imprisonment for a maximum of 5 (five) years.

Article 85:

(1)Every health personnel of a foreign national who intentionally provided health services without having a temporary STR/Registration Letter as referred to in Article 55 paragraph (1), shallbe punish- 
ed with a fine of one hundred million rupiah.

In performing medical action, it required a collaborative activity between doctors and other health personnels. Medical treatment services can only be done based on a written request from a doctor. It was clear that medical action can only be done by doctors. If a doctor could not perform medical action, the doctor can ask for help from the nurse to perform the action, with the requirement that the doctor was obliged to give clear authority to the nurse in written form to perform the medical action.

From the results of the study, it can be concluded that:

1. Nurses accountability who perform circumcision, among others:

Legal accountability that arised was related to the implementation of the profession, if the nurse performed circumcision practice, it could be in the form of responsibility for the following provisions: civil law accountability (if there was an element of compensation, for example if there was a negligence or mistake made by a health personnel in a medical action), criminal accountability (if there was evidence of an action in a health service that has an element of crime in accordance with the Indonesian Laws and Regulations Number 36 of 2009 Article 191 and Law Number 36 of 2014 Article 84 and 85). While administrative accountability was in Law Number 36 of 2009 Article 23, Law Number 36 of 2014 Article 46, Regulation of the Minister of Health of the Republic of Indonesia Number 17 of 2013 concerning Amendments to the Regulation of the Minister of Health Number Hk.02.02/Minister of Health/148/I/2010 Regarding Permits and Organizing of Nurse Practices in Article 3 which was closely related to the existence of a Practical License owned by health personnels.
The ideal construction rules for nurses to risk circumcision practices were as follows:

Referring to Article 65 of Law Number 36 of 2014 concerning Health Personnel, there was devolution of actions if the action was the authority of a doctor and delegated to the nurse. In the Regulation of the Minister of Health of the Republic of Indonesia Number 17 of 2013 concerning Amendments to the Regulation of the Minister of Health Number Hk. 022.-02/Minister of Health/148/I/2010 Regarding Permits and Implementation of Nurse Practices which stated that medical treatment services can only be done based on written requests from doctors. If the doctor could not perform the medical action, the doctor can ask for help from the nurse to perform the action, with the requirement that the doctor was obliged to give clear authority to the nurse in written form to perform the medical action. Based on the Regulation of the Minister of Health of the Republic of Indonesia Number 17 of 2013 concerning Amendments to the Regulation of the Minister of Health Number Hk.02.02/MENKES/148/I/2010 concerning Permits and Implementation of Nurse Practices of Article 3a, which stated that a Nurse Work Permit (SIKP) was a written evidence of granting authority to perform nursing practice in health care facilities outside the independent practice. In the regulation of nurse's legal accountability and the existence of stronger legal protection, the authors only suggested to create a more binding legal regulation regarding the practice of circumcision by nurses such as the addition of articles in Law No. 36 of 2014 because if it was only based on Ministerial Regulation, then the rule has no strong binding. 
From the results of this study, the author suggests:

1) For Health Personnels

It is expected that health personnels can give complete and thorough information to the patients before conducting medical action in the form of a medical approval letter which is actually a form of patients authority.

2) For the Government

The supervision of nurses' independent practices should be improved. Provisions regarding the independent practice of nurses have not been regulated in an explicit, clear and detailed manner. This can lead to multiple interpretations of legal uncertainty. The government should provide legal certainty in regulations which related to independent practice so that there are stronger rules of legal protection for independent practice of nurses who perform circumcision practice.

3) For the Community

For certain patients and communities, they must be careful in giving their approval to the actions that will be conducted.

\section{REFERENCES}

Ferris JA. et al. (2010).Circumcision in Australia: further evidence on its effects on sexual health and wellbeing, (2): 160-164. doi: 10.1111/j.1753-6405.2010.00501.x.
Hukun F, Jambi U(2009). Pertanggungjawaban hukum perawat dalam penyelenggaraan pelayanan kesehatan di rumah sakit. abstrak. 11: 45-52.

Ismani N (2001). EtikaKeperawatan.

Subarkah I (2010). Kebebasan dalam kekuasaan peradilan pidana, 77-84.

Tutik S, Hariyati (1992). Aspek Legal Perawatan sebagai Salah Satu Upaya Menyiasati Era Globalisasi Dosen Bagian Dasar Keperawatan \& Keperawatan Dasar FIK-UI, (23).

Undang-Undang Dasar Negara Republik Indonesia Tahun 1945

Undang-Undang Nomor 29 Tahun 2004 tentang Praktik Kedokteran;

Undang-Undang Nomor 36 Tahun 2009 tentang Kesehatan;

Undang-Undang Nomor 36 Tahun 2014 tentang Tenaga Kesehatan;

Undang-undang Nomor 38 Tahun 2014 tentang Keperawatan

Permenkes No. HK.02.02/MENKES/148/I/2010 tentang Izin dan Penyelenggaraan Praktik Perawat

Peraturan Menteri Kesehatan Republik Indonesia Nomor 17 Tahun 2013 Tentang Perubahan Atas Peraturan Menteri Kesehatan NomorHk.02.02/MENKES/148/I/2010 Tentang Izin dan Penyelenggaraan Praktik Perawat. 